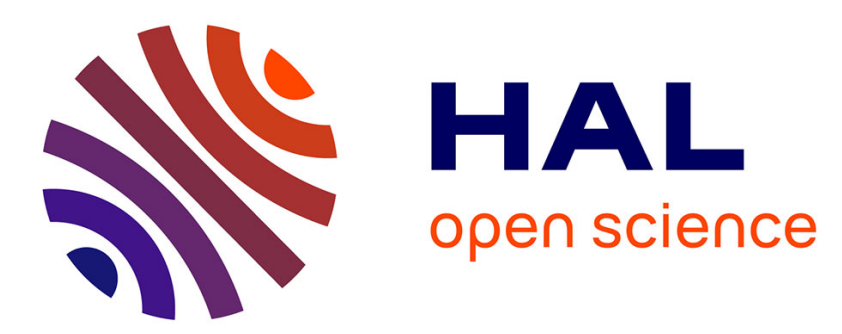

\title{
Ethyl-substituted beta-casein. Study of differences between esterified and reductively alkylated beta-casein derivatives
}

J.M. Chobert, A. Touati, C. Bertrand-Harb, Michèle Dalgalarrondo, M.G. Nicolas, Thomas Haertlé

\section{To cite this version:}

J.M. Chobert, A. Touati, C. Bertrand-Harb, Michèle Dalgalarrondo, M.G. Nicolas, et al.. Ethylsubstituted beta-casein. Study of differences between esterified and reductively alkylated beta-casein derivatives. Journal of Agricultural and Food Chemistry, 1990, 38 (6), pp.1321-1326. hal-02712869

\section{HAL Id: hal-02712869 \\ https://hal.inrae.fr/hal-02712869}

Submitted on 1 Jun 2020

HAL is a multi-disciplinary open access archive for the deposit and dissemination of scientific research documents, whether they are published or not. The documents may come from teaching and research institutions in France or abroad, or from public or private research centers.
L'archive ouverte pluridisciplinaire HAL, est destinée au dépôt et à la diffusion de documents scientifiques de niveau recherche, publiés ou non, émanant des établissements d'enseignement et de recherche français ou étrangers, des laboratoires publics ou privés. 


\title{
Ethyl-Substituted $\beta$-Casein. Study of Differences between Esterified and Reductively Alkylated $\beta$-Casein Derivatives
}

\author{
Jean-Marc Chobert, ${ }^{*}$ Abdelmadjid Touati, ${ }^{\ddagger}$ Catherine Bertrand-Harb, Michèle Dalgalarrondo, \\ Marie-Georgette Nicolas, and Tomasz Haertlé
}

Institut National de la Recherche Agronomique, Laboratoire d'Etude des Interactions des Molécules Alimentaires, B.P. 527, 44026 Nantes Cedex 03, France

\begin{abstract}
$\beta$-Casein carboxyl or amino groups were modified either by reaction with ethanol in acidic condition or by reaction with acetaldehyde via reductive alkylation at $\mathrm{pH} 8$, respectively. Different degrees of esterification and alkylation were obtained. The extent of hydrolysis after $48 \mathrm{~h}$ of alkylated $\beta$-casein by $\alpha$-chymotrypsin decreased, depending on the degree of alkylation. The conformation of alkylated $\beta$-casein was different from that of the native $\beta$-casein. Mean isoionic points for ester derivatives were $5.75,7.80,9.30$, and 9.75 as compared to 5.30 for $\beta$-casein; those of alkyl derivatives were not significantly changed. Solubilities and emulsifying activities of ethyl-esterified $\beta$-casein were significantly lower than that of native $\beta$-casein. Solubilities of ethyl-alkylated $\beta$-casein were not significantly changed as compared to native $\beta$-casein, but their emulsifying activities were higher than that of native $\beta$-casein.
\end{abstract}

\section{\begin{tabular}{l|l}
\hline InTentaire & \\
\hline No & 823
\end{tabular}}

The properties of proteins can be significantly altered by physical, chemical, and enzymatic treatment. There is an extensive literature on this subject (Kinsella, 1976; Whitaker and Puigserver, 1982; Kilara and Sharkasi, 1986; Feeney, 1987; Jimenez-Flores and Richardson, 1987; Chobert and Mesnier, 1988; Iung and Linden, 1988, and references cited therein).

Chemical modification has been proposed and tested as one of the ways to improve solubility and nutritional quality of alimentary proteins (Franzen and Kinsella, 1976; Barman et al., 1977; Feeney, 1987).

Amphipathic properties of some nutritive proteins facilitate their aggregation at interfaces, which is induced by the clusters of polar and nonpolar amino acid residues. This phenomenon driven by the hydrophilic/hydrophobic domains on the surface of proteins is widely exploited in the stabilization of foams and emulsions. Unique functional properties of milk proteins make them especially useful in these applications. $\beta$-Casein is one of the most tension-active milk proteins (Mitchell et al., 1970; Benjamin et al.; 1975; Dickinson et al., 1985). This particular feature may be attributed to the amphiphilic properties of its molecule. Considering the important contribution of $\beta$-casein to the surface properties of whole casein, modification of this protein altering in any way its interface action may be of special interest. Recently, the contribution of tryptic modifications to the solubility and emulsifying properties of $\beta$-casein has been determined (Chobert et al., 1989).

Modification of the functional properties of $\beta$-casein may result from the change of the protein net charge from negative to positive at $\mathrm{pH} 7$. It is possible to induce positive charges on the proteins by adding positively charged functions or substituting negative ones. Esterification with alcohol has proven useful for blocking

$\mp$ On a fellowship from the Institut National d'Enseignement Supérieur de Biologie, Laboratoire de Biochimie Appliquée, 15000 Tizi Ouzou, Algeria. exposed carboxyl groups in proteins (Wilcox, 1972). On the other side, alkylation leads to retention in the number of positive charges in proteins (Means and Feeney, 1968).

Correlation of chemical and functional properties of proteins can provide further insight into the possible ways of tailoring new properties of derivatized proteins for specific nutritive applications. Already existing studies are often difficult to compare because of lack of standardized methods of measure of the functional properties. Because of their objectives, they are difficult to analyze, being frequently highly irreproducible multicomponent mixtures.

The aim of this work was to determine systematically the effects of the esterification of carboxyl groups or alkylation of amino groups on some physicochemical and functional properties of the modified $\beta$-casein. We wanted also to analyze the influence of the degree of these substitutions.

\section{MATERIALS AND METHODS}

Preparation of $\beta$-Casein. Crude $\beta$-casein A1 was prepared as described in Zittle and Custer (1963) from the milk of a cow homozygous at the four casein loci. This fraction was then chromatographed, according to the method of Mercier et al. (1968), on a Q-Sepharose fast-flow column $(5 \times 50 \mathrm{~cm}$; Pharmacia, Uppsala, Sweden). The elution of $\beta$-casein from the column was carried out with $0.02 \mathrm{M}$ imidazole hydrochloride buffer ( $\mathrm{pH} 7.0$ ) containing $3.3 \mathrm{M}$ urea under a linear gradient of $\mathrm{NaCl}(0.15 \rightarrow$ $0.30 \mathrm{M}$ ). The $\beta$-casein fraction was dialyzed against distilled water and then freeze-dried. The homogeneity of the final product was checked by electrophoresis and RP-HPLC. The concentration of the $\beta$-casein solution was determined after filtration on $0.45-\mu \mathrm{m}$ filters, from the extinction coefficient $E_{1 \mathrm{mg} / \mathrm{mL}}^{280 \mathrm{~m}}$ $=0.46$ given by Swaisgood (1982).

Chemicals and Enzyme. Organic solvents used for HPLC were from Carlo Erba. All other reagents were of analytical grade. Buffers and solvents for HPLC were filtered through Millipore 0.45- $\mu \mathrm{m}$ filters (Millipore Corp., Bedford, MA) and degassed under vacuum before use. Bovine chymotrypsin treated with $N^{\alpha}$-p-tosyl-t-lysine chloromethyl ketone (40-50 units/ $\mathrm{mg}$ ), PTH amino acid standards, sodium cyanoborohydride, 2,4,6trinitrobenzenesulfonic acid (TNBS), and L-leucine were obtained 
Table I. Extent of Esterification of $\beta$-Casein with Ethanol

\begin{tabular}{cccc}
\hline samples & $\begin{array}{c}\text { molarity in } \\
\mathrm{HCl}, \mathrm{N}\end{array}$ & $\mu$ mol of ester & $\begin{array}{c}\text { degree of } \\
\text { esterification, \% }\end{array}$ \\
\hline est A & 0.06 & 1.75 & $37 \pm 0.4$ \\
est B & 0.12 & 2.05 & $43 \pm 0.2$ \\
est C & 0.23 & 3.30 & $69 \pm 0.5$ \\
est D & 0.68 & 4.50 & $94 \pm 0.1$
\end{tabular}

a Ethyl acetate was used as a standard.

Table II. Extent of Alkylation* of $\beta$-Casein with Acetaldehyde

\begin{tabular}{cccc}
\hline & $\begin{array}{c}\text { mol of } \\
\text { samples }\end{array}$ & \multicolumn{2}{c}{ \% lysine alkylated as measured by } \\
\cline { 3 - 4 } (CHO/ & group & TNBS & $\begin{array}{c}\text { amino acid } \\
\text { analysis }\end{array}$ \\
\hline alk A & 1.75 & 52 & 64 \\
alk B & 3.50 & 76 & 82 \\
alk C & 7.00 & 81 & 91 \\
alk D & 14.00 & 89 & 100
\end{tabular}

a Alkylation was performed with $4.17 \times 10^{-5} \mathrm{M}$ casein and varying concentrations of carbonyl reagent at $\mathrm{pH} 8.0$ in the presence of $0.035 \mathrm{M} \mathrm{NaBH}_{3} \mathrm{CN}$

from Sigma Chemical Co.; $6 \mathrm{~N}$ hydrochloric acid, phenyl isothiocyanate (PITC), and amino acid standards were from Pierce Chemical Co. Rapeseed oil was from Carrefour, France.

Preparation of Esterified $\beta$-Casein. Esters of $\beta$-casein were prepared by using a modification of the procedure described by Fraenkel-Conrat and Olcott (1945). Purified $\beta$-casein, dried for $\mathbf{4 8 ~} \mathrm{h}$ under nitrogen, was then suspended in cold ethanol to give a $2 \%$ suspension. While the protein-ethanol suspension was stirred, concentrated $\mathrm{HCl}$ was slowly added to make the suspension $0.06-0.68 \mathrm{~N}$ in $\mathrm{HCl}$ (Table I). Each mixture was stirred at $4{ }^{\circ} \mathrm{C}$ for 10 days and then washed under vacuum 3 times with ethanol and finally with ethyl acetate. Dried samples were stored at $-80^{\circ} \mathrm{C}$. Appropriate control was prepared in the same manner in the absence of $\mathrm{HCl}$. The overall weight yields of all control and esterified $\beta$-casein preparations were $\sim 90 \%$.

Analysis of Esterified $\beta$-Casein. To quantify the extent of esterification of $\beta$-casein with ethanol, the color reaction using hydroxylamine hydrochloride developed by Halpin and Richardson (1985) was used with modifications according to BertrandHarb et al. (1989).

Preparation of Alkylated $\beta$-Casein. The procedures for alkylation were performed in general according to the method of Means and Feeney (1968). All alkylations were done at room temperature $\left(23^{\circ} \mathrm{C}\right)$. A $2 \%$ solution $(50 \mathrm{~mL})$ of $\beta$-casein in 0.2

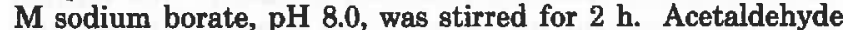
and reductive reagent (sodium cyanoborohydride) were then added. The amount of aldehyde was varied according to Table II to produce various degrees of modification. The reaction mixture was stirred for $24 \mathrm{~h}$ and then dialyzed against $3 \mathrm{mM}$ triethylamine, $\mathrm{pH} 9$, for 2 days and lyophilized. Appropriate control was prepared in the same manner in the absence of carbonyl reagent. The overall weight yields of all control and alkylated $\beta$-casein preparations were $\sim 70 \%$.

Analysis of Alkylated $\boldsymbol{\beta}$-Casein. The degree of alkylation was determined by quantitating the decrease in free amino groups with TNBS (Adler-Nissen and Olsen, 1979) and by measuring the loss in lysine by amino acid analysis.

Amino Acid Analysis. After acid hydrolysis under vacuum in the presence of $6 \mathrm{~N} \mathrm{HCl}$ for $24 \mathrm{~h}$ at $110^{\circ} \mathrm{C}$ in a PicoTag station (Waters), amino acids were derivatized with PITC according to the method of Bidlingmeyer et al. (1984) and quantified by RP-HPLC on a Pico-Tag C-18 column (3.9 mm i.d. $x$ $15 \mathrm{~cm}$, Waters). Dried samples were dissolved in $95 \% 2 \mathrm{mM}$ $\mathrm{Na}_{2} \mathrm{HPO}_{4}$, $\mathrm{pH} 7.4 / 5 \%$ acetonitrile. The HPLC column was equilibrated in solvent $\mathrm{A}\left(94 \% 0.14 \mathrm{M} \mathrm{CH}_{3} \mathrm{COONa}+0.5 \mathrm{~mL}\right.$ of TEA/L, pH $6.4 / 6 \%$ acetonitrile). Column elution was performed with a gradient from solvent $A$ to solvent $B\left(40 \% \mathrm{H}_{2} \mathrm{O}\right.$ / $60 \%$ acetonitrile) with a flow rate of $1 \mathrm{~mL} / \mathrm{min}$. Both the column and solvents were maintained at $38{ }^{\circ} \mathrm{C}$. Absorbance was recorded at $254 \mathrm{~nm}$. The HPLC equipment consisted of an autosampling injector Model 231 (Gilson, France), assisted by a chromatography work station Maxima 820, an APC IV computer, and a pin writer P6 (NEC Corp., Boxborough), two solvent delivery systems Model 510, a temperature control system, and a variable-wavelength UV monitor Model 455 (Waters Associates, Milford, MA).

Isoionic Points. Ten milligrams of protein was dissolved in $10 \mathrm{~mL}$ of distilled water with stirring. Mixed-bed ionexchange resin (1.5 g; AG 501-X-8, Bio-Rad, Richmond, CA) was added to the protein solution and the $\mathrm{pH}$ monitored until it became constant. The isoionic point of each protein was considered to be attained at this $\mathrm{pH}$, and proteins of known isoionic points were used as standards (Ho and Waugh, 1965).

In Vitro Hydrolysis. The degree of hydrolysis of $\beta$-casein and alkylated $\beta$-casein by $\alpha$-chymotrypsin was determined by measuring the amount of amino groups liberated with TNBS (Adler-Nissen and Olsen, 1979). The reaction mixtures contained $0.2 \%$ native or alkylated $\beta$-casein in $0.02 \mathrm{M}$ borate buffer, pH 8.25 , and the reaction was performed at $38^{\circ} \mathrm{C}$. For determination of rates and extent of hydrolysis, assays were done with an $E / S$ ratio of $1 \%$. Aliquots removed at intervals for a period of $48 \mathrm{~h}$ were quenched by $0.05 \mathrm{~N} \mathrm{HCl}$.

Fluorescence Spectra of Alkylated $\beta$-Casein. Equal concentration $\left(A_{280 \mathrm{~nm}}=1.0\right)$ solutions of native and alkylated $\beta$-casein were prepared in $0.2 \mathrm{M}$ sodium phosphate buffer, $\mathrm{pH}$ 7.10. Emission' spectra were recorded on a SLM Aminco Model $4800 \mathrm{C}$ fluorescence spectrophotometer equipped with a thermostated cell holder and an expanding recorder at excitation wavelength 280 and $300 \mathrm{~nm}$. All measurements were done in 1-cm quartz cells with a 1-nm excitation and emission slit width.

Chemical Stability of Ester Groups. The stability of the ester groups at various $\mathrm{pH}$ values was determined by dissolving $2 \mathrm{mg}$ of esterified protein in $250 \mu \mathrm{L}$ of buffer (alternatively $0.1 \mathrm{M}$ sodium phosphate, $\mathrm{pH} 7.0$ and $8.2 ; 0.1 \mathrm{M}$ sodium citrate, $\mathrm{pH} 2.4$, and $5.1 ; 0.1 \mathrm{M}$ sodium bicarbonate, $\mathrm{pH} 10.5$ ) and incubating $24 \mathrm{~h}$ at $26^{\circ} \mathrm{C}$. Saponification was performed by dissolving esterified protein in $250 \mu \mathrm{L}$ of $0.1 \mathrm{~N} \mathrm{NaOH}$ (pH 13.7). The degree of esterification was then measured as described above.

Solubility. Native, alkylated, and esterified $\beta$-caseins were dispersed in distilled water $(0.1 \% \mathrm{w} / \mathrm{w})$ by mixing with the help of a shaker. The $\mathrm{pH}$ was adjusted from 1.0 to 11.0 by using concentrated $\mathrm{HCl}$ or $\mathrm{NaOH}$ to limit dilution. After an equilibration period of $10 \mathrm{~min}$ at room temperature $\left(23^{\circ} \mathrm{C}\right)$, a portion of each solution was used to determine emulsifying properties. The remainder was centrifuged for $15 \mathrm{~min}$ at $4^{\circ} \mathrm{C}$ (centrifuge Sigma 201) at $5000 \mathrm{rpm}(2700 \mathrm{~g})$. The protein content in the supernatant was determined by the method of Lowry et al. (1951) with $\beta$-casein or modified $\beta$-casein as standards. The solubility was expressed as a percentage of total protein concentration.

Emulsifying Activity. Three milliliters of $0.1 \%$ protein solution at desired $\mathrm{pH}$ and $1 \mathrm{~mL}$ of rapeseed oil $(\Phi$, volume fraction of the dispersed phase $=0.25$ ) were shaken together and homogenized at $20000 \mathrm{rpm}$ for $30 \mathrm{~s}$ at room temperature (Kinematica GmbH Polytron equipped with a Reco $20 \mathrm{~T}$ speed and time control system). The emulsifying activity of the caseins was evaluated by spectroturbidity according to the method of Pearce and Kinsella (1978), with slight modification. The aliquots were immediately taken from the emulsion and diluted 500 -fold into $0.1 \%(\mathrm{w} / \mathrm{v}$ ) SDS in $0.1 \mathrm{M} \mathrm{NaCl}, \mathrm{pH} 7.0$. The tubes were inverted three times to obtain homogeneous mixtures, and then absorbance at $500 \mathrm{~nm}$ was recorded. Identical $1 \mathrm{~cm}$ path length glass cuvettes were used and were rinsed with a jet of distilled water and dried between two determinations. Absorbancies of duplicate aliquots of each emulsion were measured and the individual values plotted. The emulsifying activity was expressed as its emulsifying activity index (EAI)

$$
\mathrm{EAI}=2 T / \Phi c
$$

where $T$ is turbidity (2.3 $A / l[A$ is absorbance at $500 \mathrm{~nm}$ and $l$ is the light path $\left.\left(1 \mathrm{~cm}=10^{-2} \mathrm{~m}\right)\right], \Phi$ is the oil phase volume $(0.25)$, and $c$ is the concentration of protein $(0.1 \%)$ before the emulsion is formed.

Emulsion Stability. The stock emulsions prepared above were held at room temperature for $24 \mathrm{~h}$ and then heated at 80 ${ }^{\circ} \mathrm{C}$ for $30 \mathrm{~min}$. After the emulsions were cooled to room temperature and stirred, turbidity was again measured as above 
Table III. Isoionic Points of $\beta$-Casein and $\beta$-Casein Derivatives

\begin{tabular}{cccc}
\hline samples & $\begin{array}{c}\text { apparent } \\
\text { isoionic point }\end{array}$ & samples & $\begin{array}{c}\text { apparent } \\
\text { isoionic point }\end{array}$ \\
\hline$\beta$-Cn & 5.30 & alk A & 5.30 \\
est A & 5.75 & alk B & 5.40 \\
est B & 7.80 & alk C & 5.20 \\
est C & 9.30 & alk D & 5.35 \\
est D & 9.75 & &
\end{tabular}

(EAI, $80^{\circ} \mathrm{C}$ ). The emulsion stability was calculated by the formula

$$
\Delta \mathrm{EAI} \%=\frac{\mathrm{EAI}-\mathrm{EAI}, 80^{\circ} \mathrm{C}}{\mathrm{EAI}} \times 100
$$

The smaller the value of $\triangle \mathrm{EAI} \%$, the better the stability.

\section{RESULTS AND DISCUSSION}

Analyses of Esterified $\beta$-Casein. The extent of esterification of $\beta$-casein with ethanol, determined by the color reaction using hydroxylamine hydrochloride, is shown in Table I. Because there are 23 carboxyl groups per $\beta$-casein molecule susceptible to esterification ( 22 combined glutamic and aspartic acid residues and 1 carboxyl end group), results of the hydroxamic acid reaction indicate that 37 , 43,69 , and $94 \%$ of the available carboxyl groups were esterified with ethanol, depending on the amount of catalyst used.

Analyses of Alkylated $\beta$-Casein. The extents of alkylation of $\beta$-casein by acetaldehyde, determined by the TNBS method and amino acid analysis, are shown in Table II. We have achieved different degrees of alkylation by varying the ratio of the alkylating agent to the amount of available amino groups. Generally, the results based on the TNBS analyses agree well with the results of amino acid analyses; $64,82,91$, and $100 \%$ of the lysine $\epsilon$-amino groups were alkylated. For all the alkylated $\beta$-casein, the losses in lysine were accompanied by a corresponding increase in the alkyllysine derivative. According to Means and Feeney (1968), the diethylamine is produced only in small amounts and at high $\mathrm{pH}(>9.5)$ with acetaldehyde. Therefore, it may be considered with some degree of probability that only the monoalkyl derivative was obtained. There were no significant changes in other amino acids of the alkylated $\beta$-casein.

Isoionic Points. Isoelectric points, determined as the $\mathrm{pH}$ at which a protein has zero mobility in an electric field, and isoionic points, the $\mathrm{pH}$ of a protein solution with no ions present except the hydrogen and hydroxyl ions produced by the dissociation of water and the protein, are generally very close in values (Mattarella et al., 1983). Isoionic points determined by adding a mixedbed ion-exchange resin to the protein solutions are shown in Table III. Isoionic points of esterified $\beta$-casein varied between 5.75 and 9.75 compared with 5.30 for native $\beta$-casein. No significant modifications could be observed for alkylated derivatives.

Extent of Hydrolysis of Alkylated $\beta$-Casein by $\alpha$-Chymotrypsin. Increases in TNBS reaction of amino groups were used to determine the rates of hydrolysis of $\beta$-casein and alkylated $\beta$-casein by chymotrypsin. Up to 60 min incubation time, the sample with $91 \%$ lysyl residues alkylated was slightly more susceptible to chymotrypsin hydrolysis as compared to native $\beta$-casein and other alkylated derivatives; the sample with $61 \%$ lysyl residues alkylated was least susceptible to hydrolysis in the first $30 \mathrm{~min}$ (data not shown). Table IV shows that after $48 \mathrm{~h}$, the extent of hydrolysis of chymotrypsin-susceptible bonds in alkylated $\beta$-casein was significantly lower
Table IV. Extent of Hydrolysis of Alkylated $\beta$-Casein by $\alpha$-Chymotrypsin after $48 \mathrm{~h}$ of Incubation

\begin{tabular}{ccc}
\hline samples & degree of alkylation, $\%$ & relative extent \\
\hline$\beta$-Cn & 0 & 100 \\
alk A & 64 & 89 \\
alk B & 82 & 74 \\
alk C & 91 & 76 \\
alk D & 100 & 73
\end{tabular}

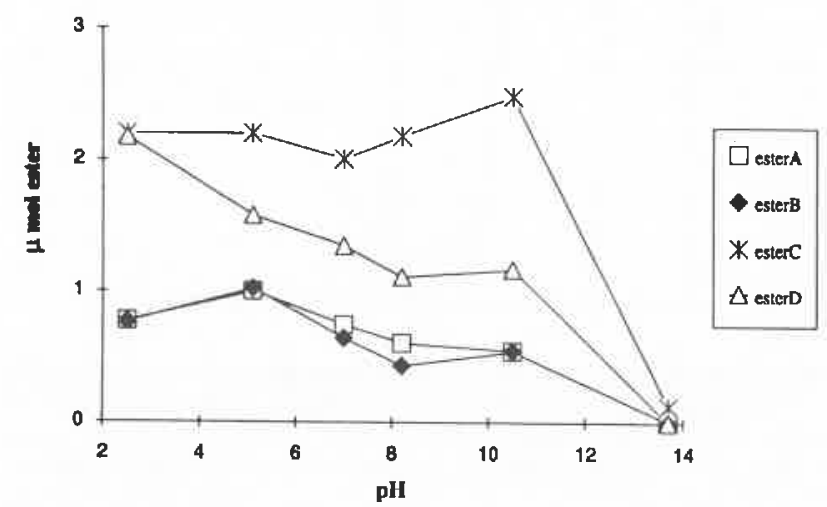

Figure 1. Stability of ester derivatives of $\beta$-casein to various $\mathrm{pH}$ values for $24 \mathrm{~h}$.

than that of native $\beta$-casein. The degree of alkylation affected the extent of hydrolysis particularly for the most alkylated derivatives (alk, A, 64\% modified, $89 \%$ relative extent; alk B-D, $82-100 \%$ modified, $73-76 \%$ relative extent).

Fluorescence Spectra. The fluorescence spectra of alkylated $\beta$-casein (data not shown) display considerable quantum yield enhancement induced by intense modification. Concomitant blue shift of the emission maximum ( $\lambda E 337 \rightarrow 334 \mathrm{~nm}$ ) may be observed above $90 \%$ alkylation. Spectral shift of the fluorescence emission maximum indicates the changes of hydrophobicity of the tryptophan neighborhood brought about by the grafting of alkyl groups (Lakowicz, 1983). The explanation of the fluorescence signal enhancement is more complex (Turro, 1978) and indicates possible rigidification of indale chromophore, induced by the chemical substitution of the $\beta$-casein. The last should be taken, however, as a tentative explanation remaining to be confirmed by other methods.

Chemical Stability of Ester Groups. The extent of hydrolysis of ester groups increased at alkaline pH (Figure 1). After $24 \mathrm{~h}$ at $\mathrm{pH} 10.5$, the amount of ester groups had decreased 70-75\% except for sample ester C, which had decreased only $25 \%$. These results differ from those of Mattarella and Richardson (1983), who observed a slow rate of hydrolysis of ester groups in ethyl-esterified $\beta$-lactoglobulin, as measured by a decrease in the isoionic point.

Solubility. (a) Esterified $\beta$-Casein. The solubility patterns of esterified $\beta$-casein at different $\mathrm{pH}$ values are shown in Figure 2. The ethyl-esterified $\beta$-casein was much less soluble at $\mathrm{pH}$ values between 5.0 and 10.0 as compared with native $\beta$-casein; the solubility was reversely proportional to the degree of esterification. For example, at $\mathrm{pH} 7.0$ ethyl-esterified $\beta$-casein gave the following results: $37 \%$ modified, $91 \%$ solubility; $43 \%$ modified, $27 \%$ solubility; $69 \%$ modified, $5 \%$ solubility; $94 \%$ modified, $2 \%$ solubility. At very alkaline $\mathrm{pH}$ values $(\mathrm{pH}>10)$, an increase in solubility was observed, especially with sample ester B, due certainly to the hydrolysis of the ester bond. This is in agreement with the results of the chemical stability study of the ester bond (Figure 1). In the acidic range of $\mathrm{pH}$ no significant change of solubility could 


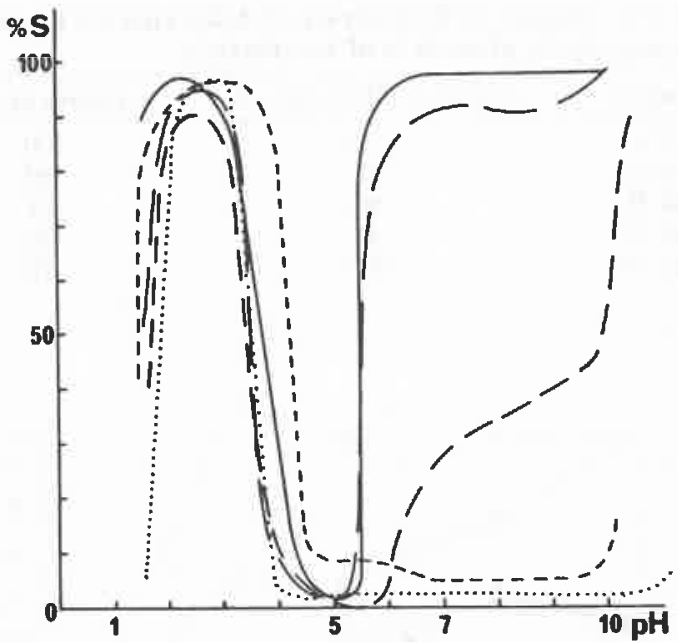

Figure 2. Solubilities of $0.1 \% \mathrm{w} / \mathrm{w}$ suspensions of native $\beta$-casein (-); ester A, 37\% modified (- - ); ester B, 43\% modified (- ); ester C, $69 \%$ modified (- - ) and ester D, 94\% modified (...) at various $\mathrm{pH}$ values; reported as mean of four determinations.

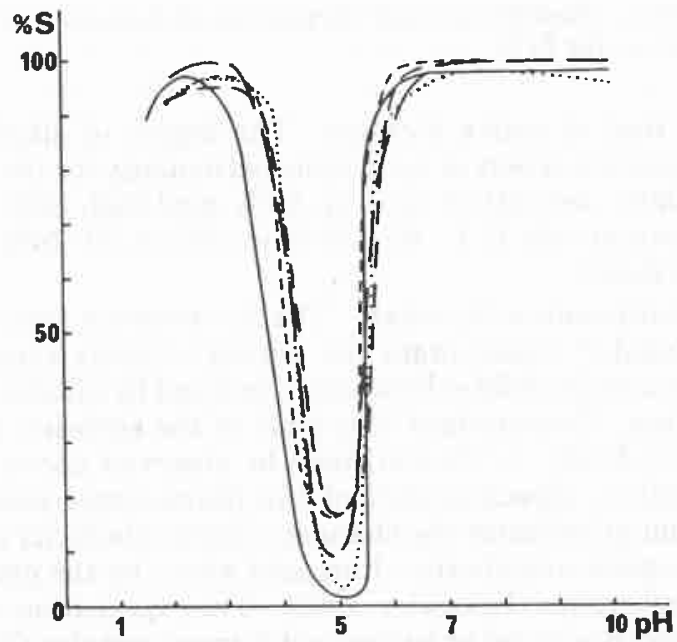

Figure 3. Solubilities of $0.1 \% \mathrm{w} / \mathrm{w}$ suspensions of native $\beta$-casein (-); alk A, 64\% modified (- $)$; alk B, $82 \%$ modified (- - ); alk C, $91 \%$ modified (--) and alk D, $100 \%$ modified (...) at various $\mathrm{pH}$ values; reported as mean of four determinations.

be observed except for an increased solubility of sample ester $\mathrm{C}$ at $\mathrm{pH} 4.0$.

(b) Alkylated $\beta$-Casein. The solubility patterns of alkylated $\beta$-casein at different $\mathrm{pH}$ values are shown in Figure 3. Alkylation does not change the number of positive charges in the protein, and only a small decrease ( $\sim 0.4-0.6$ unit) in the $\mathrm{p} K_{\mathrm{a}}$ of the amino group can be observed (Means and Feeney, 1968). Ethyl-alkylated $\beta$-caseins were slightly more soluble than native $\beta$-casein in the $\mathrm{pH}$ range 3.0-5.0. Above $\mathrm{pH}$ 6.0, there was no significant difference between alkylated and native $\beta$-casein. These results agree well with those reported by Sen et al. (1981), who demonstrated that methyl- or isopropyl-alkylated whole casein was significantly more soluble than native whole casein in the $\mathrm{pH}$ range 3.0-6.0 when in the case of butyl-, cyclohexyl-, and benzyl-alkylated whole casein, they have observed an overall decrease in solubility from $\mathrm{pH} 3.0$ to 10.0 due to the presence of much larger hydrophobic groups.

$\beta$-Casein is in a random coil configuration with very little helical structure (Slattery, 1976). Upon alkylation, the grafting of hydrophobic ethyl residues (7-12 residues/mol) may induce some rudimentary folding driven by increased hydrophobic interactions. At pH below 10,

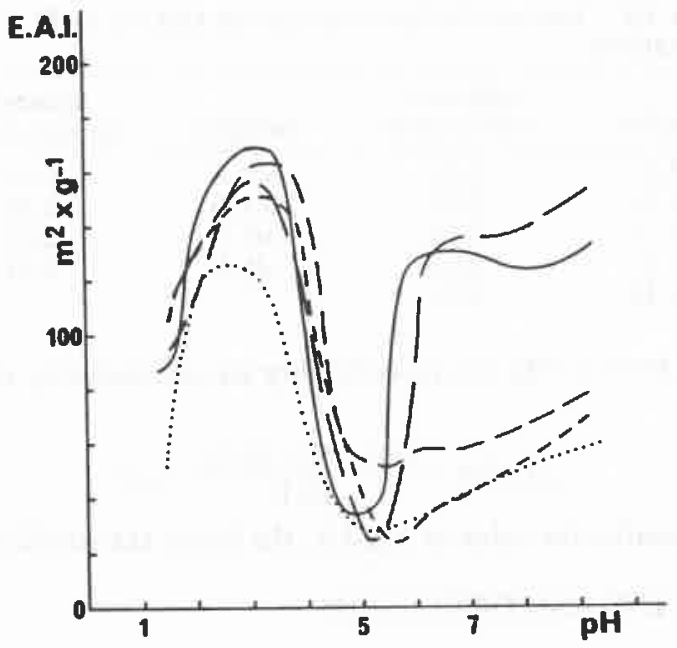

Figure 4. Emulsifying activity index of native and esterified $\beta$-casein as a function of pH. Symbols as in Figure 2; reported as mean of four determinations.

Table V. Emulsion Stability of Ester Derivatives of $\beta$-Casein ( $\triangle \mathrm{EAI} \%$ )

\begin{tabular}{cccccl}
\hline $\mathrm{pH}$ & $\beta-\mathrm{Cn}$ & est A & \multicolumn{1}{c}{ est B } & est C & \multicolumn{1}{c}{ est D } \\
\hline 2 & $18.2 \pm 1.0$ & $9.0 \pm 0.3$ & $14.3 \pm 5.0$ & $8.0 \pm 3.0$ & nd $^{\mathbf{a}}$ \\
3 & $28.6 \pm 1.5$ & $18.6 \pm 3.0$ & $33.8 \pm 7.2$ & $8.5 \pm 2.1$ & nd $^{a}$ \\
4 & $30.8 \pm 0.1$ & $16.8 \pm 10.0$ & $33.6 \pm 1.5$ & nd $^{a}$ & $8.9 \pm 3.0$ \\
6 & nd $^{a}$ & $4.9 \pm 2.5$ & nd $^{\alpha}$ & nd $^{a}$ & nd $^{a}$ \\
7 & $1.5 \pm 1.5$ & $21.6 \pm 1.0$ & nd $^{a}$ & $10.5 \pm 1.4$ & $4.2 \pm 0.3$ \\
8 & $5.6 \pm 1.7$ & $7.6 \pm 2.5$ & $5.7 \pm 6.0$ & $27.6 \pm 5.6$ & $35.3 \pm 1.4$ \\
9 & $5.3 \pm 0.5$ & $17.5 \pm 2.6$ & $22.5 \pm 3.8$ & $36.7 \pm 4.0$ & $34.0 \pm 2.7$ \\
\multicolumn{5}{c}{ a nd, not determined because of emulsion collapse. }
\end{tabular}

due to the electrostatic repulsion between still positively charged amino nitrogens, the hydrophobic interactions between introduced hydrophobic residues are weaker than they might be otherwise. In the case of ethyl-esterified derivatives, a greater number ( $8-22$ residues/mol) of hydrophobic ethyl residues were attached to $\beta$-casein. Consequently, the number of salt bridges was decreased due to the loss of several negatively charged carboxylates. This could tentatively explain the poor solubility of ester derivatives in the $\mathrm{pH}$ range 5.0-10.0.

Emulsifying Activity and Emulsion Stability. (a) Esterified $\beta$-Casein. Native $\beta$-casein had better emulsifying activity than any of the modified proteins under the conditions used in the $\mathrm{pH}$ ranges $1.0-3.0$ and 5.59.0 , except for the less esterified derivative, which had an emulsifying activity slightly increased in the $\mathrm{pH}$ range 7.0-9.0 (Figure 4). The extent of deviation from that of native $\beta$-casein correlated with the extent of modification. The higher the esterification, the smaller were both the emulsifying activity and the emulsion stability (Table $\mathrm{V})$, in $\mathrm{pH}$ values above 5.5 .

(b) Alkylated $\beta$-Casein. In contrast to esterified $\beta$-caseins, all alkylated $\beta$-caseins had better emulsifying activity than native $\beta$-casein under the conditions used, in the $\mathrm{pH}$ ranges 1.0-4.0 and 5.5-9.0 (Figure 5). At pH 2.5 , the less alkylated derivative had the best emulsifying activity. Higher alkylated derivatives had better emulsifying activities in the $\mathrm{pH}$ range 6.0-9.0. In general, alkylated derivatives showed a better emulsion stability in the acidic range of $\mathrm{pH}$ as compared with native $\beta$-casein (Table VI).

The utilization of surplus milk proteins in general may be increased through a fundamental understanding of structural factors contributing to the transformations of their properties. Furthermore, useful nontoxic derivatives of milk proteins may find applications as more sophis- 


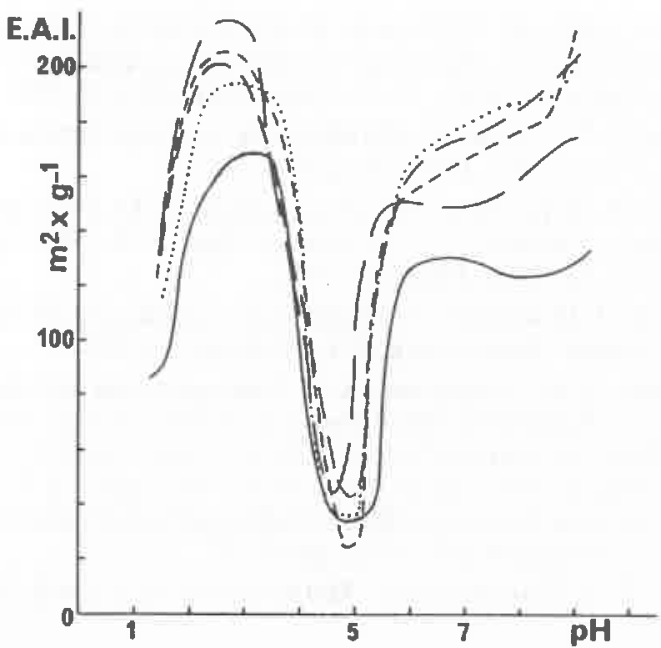

Figure 5. Emulsifying activity index of native and alkylated $\beta$-casein as a function of $\mathrm{pH}$. Symbols as in Figure 3; reported as mean of four determinations.

Table VI. Emulsion Stability of Alkyl Derivatives of $\beta$-Casein ( $\triangle \mathrm{EAI} \%$ )

\begin{tabular}{cccccc}
\hline $\mathrm{pH}$ & $\beta-\mathrm{Cn}$ & alk A & alk B & alk C & alk D \\
\hline 2 & $18.2 \pm 1.0$ & $34.5 \pm 0.6$ & $5.5 \pm 0.05$ & $10.5 \pm 1.1$ & 0.0 \\
3 & $28.6 \pm 1.5$ & $27.6 \pm 1.0$ & $13.9 \pm 0.6$ & $12.7 \pm 0.7$ & $9.6 \pm 0.03$ \\
4 & $30.8 \pm 0.1$ & $21.6 \pm 4.4$ & $8.1 \pm 1.6$ & $12.8 \pm 1.1$ & $14.5 \pm 1.6$ \\
6 & nd $^{a}$ & $20.7 \pm 0.2$ & $13.1 \pm 0.06$ & $9.8 \pm 0.7$ & $8.1 \pm 0.1$ \\
7 & $1.5 \pm 1.5$ & $19.6 \pm 0.3$ & $9.1 \pm 0.15$ & $3.6 \pm 0.6$ & $5.6 \pm 1.6$ \\
8 & $5.6 \pm 1.7$ & $12.7 \pm 0.6$ & $1.1 \pm 1.0$ & $7.8 \pm 0.2$ & $15.6 \pm 0.1$ \\
9 & $5.3 \pm 0.5$ & nd $^{a}$ & $2.9 \pm 0.5$ & $9.4 \pm 0.2$ & $9.4 \pm 2.0$
\end{tabular}

a nd, not determined because of emulsion collapse.

ticated food additives. The studies of chemically and physically induced protein transformations may, in the future, yield valuable structural information for designing and producing more diversified food proteins for miscellaneous uses. Numerous studies on chemically modified alimentary proteins have established the usefulness of this approach (Kinsella, 1976; Kinsella and Shetty, 1979; Sen et al., 1981; Mattarella and Richardson, 1983). It seems reasonable to expect that only extensive conformational changes can induce modification of the physical properties studied in this work in proteins lacking tertiary structure, such as caseins. Those, in turn, might be imposed by the application of nontoxic chemistry.

Grafting of hydrophobic groups by reductive alkylation changed the conformation of $\beta$-casein in the neighborhood of tryptophan as shown by the fluorescence spectra. Solubilities were slightly increased over that of native $\beta$-casein in the acidic range of $\mathrm{pH}$ and were not decreased in its alkaline part. Thus, the covalent attachment of hydrophobic groups to proteins may increase emulsifying activities of food proteins. Moreover, reductive alkylation may be useful as a mean of protection of the lysyl residues against deteriorative reactions such as nonenzymatic browning during food processing and storage, resulting in the development of the certain taste, color, and odor (both desirable and undesirable) of some food. One must be aware of the fact, however, that greater extent of alkylation induces lower digestibility of the alkylated $\beta$-casein by $\alpha$-chymotrypsin (Table IV). This may or may not have an adverse effect on the nutritional quality of the modified protein (Matoba et al., 1980), especially when the alkylated protein constitutes only a small fraction of the total. Even considering their limited digestibility, the alkylated proteins could be used as a filler in the foods ingested during weight-watching diets. Derivatization of nonessential amino acid residues such as gluta- mate and aspartate could represent a more desirable approach to formulate novel yet nutritious proteins. However, while emulsifying activity and emulsion stability of ethyl-esterified $\beta$-lactoglobulin were greatly increased (Mattarella and Richardson, 1983), the ethyl-esterified $\beta$-casein had poor solubility and emulsifying activity. The data reported in this paper illustrate that one must be very careful in the proper choice of chemical modification methods in food proteins.

\section{LITERATURE CITED}

Adler-Nissen, J.; Olsen, H. S. The influence of peptide chain length on taste and functional properties of enzymatically modified soy protein. In Functionality and Protein Structure; Pour-El, A., Ed.; Advances in Chemistry Series 92; American Chemical Society: Washington, DC, 1979; pp 125-146.

Barman, B. G.; Hansen, J. R.; Mossey, A. R. Modification of the physical properties of soy protein isolate by acetylation. J. Agric. Food Chem. 1977, 25, 638-641.

Benjamin, J.; de Feijter, J. A.; Evans, M. T. A.; Graham, D. E.; Phillips, M. C. Dynamic and static properties of proteins adsorbed at the air-water interface. Faraday Discuss. Chem. Sac. 1975, 59, 218-229.

Bertrand-Harb, C.; Chobert, J. M.; Dufour, E.; Haertle, T. Characterization of ester derivatives of proteins via colorimetric measurement of the corresponding $\mathrm{Fe}$-hydroxamate chelate. Anal. Biochem. 1989 (submitted for publication).

Bidlingmeyer, B. A.; Cohen, S. A.; Tarvin, T. L. Rapid analysis of amino acids using pre-column derivatization. J. Chromatogr. 1984, 336, 93-104.

Chobert, J. M.; Mesnier, D. Procédés chimiques d'amélioration des propriétés fonctionnelles des protéines alimentaires. In Propriétés Fonctionnelles des Macromolécules Alimentaires; Les Cahiers de l'ENS.BANA; Technique et Documentation-Lavoisier: Paris, 1988; pp 175-198.

Chobert, J. M.; Bertrand-Harb, C.; Dalgalarrondo, M.; Nicolas, M. G. Solubility and emulsifying properties of beta-casein modified enzymatically by trypsin. J. Food Biochem. 1989, 13, 335-352.

Dickinson, E.; Pogson, D. J.; Robson, E. W.; Stainsby, G. Timedependent surface pressure of adsorbed films of caseinate and gelatin at the oil-water interface. Colloids Surf. 1985, 14, 135-141.

Feeney, R. E. Chemical modification of proteins: comments and perspectives. Int. J. Pept. Protein Res. 1987, 29, 145-161.

Fraenkel-Conrat, H.; Olcott, H. S. Esterification of proteins with alcohols of low molecular weight. J. Biol. Chem. 1945, 161, 259-268.

Franzen, K. L.; Kinsella, J. E. Functional properties of succinylated and acetylated soy proteins. J. Agric. Food Chem. $1976,24,788-795$.

Halpin, M. I.; Richardson, T. Selected functionality changes of $\beta$-lactoglobulin upon esterification of side-chain carboxyl groups. J. Dairy Sci. 1985, 68, 3189-3198.

Ho, C.; Waugh, D. F. Interactions of bovine $\alpha_{\mathrm{S1}}$-casein with small ions. J. Am. Chem. Soc. 1965, 87, 110-117.

Iung, C.; Linden, G. Procédés enzymatiques de modification des propriétés fonctionnelles des macromolécules alimentaires. In Propriétés Fonctionnelles des Macromolécules Alimentaires; Les Cahiers de l'ENS.BANA; Technique et Documentation-Lavoisier: Paris, 1988; pp 199-223.

Jimenez-Flores, R.; Richardson, T. Effects of chemical, genetic and enzymatic modifications on protein functionality. In Food Biotechnology; King, R. D., Cheetham, P. S. J., Eds.; Applied Science: London, 1987; Vol. 1, pp 87-137.

Kilara, A.; Sharkasi, T. Y. Effects of temperature on food proteins and its implications on functional properties. $C R C$ Crit. Rev. Food Sci. Nutr. 1986, 23, 323-395.

Kinsella, J. E. Functional properties of proteins in foods: a survey: CRC Crit. Rev. Food Sci. Nutr. 1976, 7, 219-280.

Kinsella, J. E.; Shetty, K. J. Chemical modification for improving functional properties of plant and yeast proteins. In Functionality and Protein Structure; Pour-El, A., Ed.; ACS Symposium Series 92; American Chemical Society: Washington, DC, 1979; pp 37-63. 
Lakowicz, J. R. In Principles of fluorescence spectroscopy; Plenum Press: New York, 1983; pp 244-245.

Lowry, O. H.; Rosebrough, N. J.; Farr, A. L.; Randall, R. S. Protein measurement with the Folin Phenol reagent. J. Biol. Chem. 1951, 193, 265-275.

Matoba, T.; Doi, E. In Vitro digestibility of succinylated protein by pepsin and pancreatic proteases. J. Food Sci. 1979, 44, 537-539.

Mattarella, N. L.; Richardson, T. Physicochemical and functional properties of positively charged derivatives of bovine B-lactoglobulin. J. Agric. Food Chem. 1983, 31, 972-978.

Mattarella, N. L.; Creamer, L. K.; Richardson, T. Amidation or esterification of bovine $\beta$-lactoglobulin to form positively charged proteins. J. Agric. Food Chem. 1983, 31, 968-972.

Means, G. E.; Feeney, R. E. Reductive alkylation of amino groups in proteins. Biochemistry 1968, 7, 2192-2201.

Mercier, J. C.; Maubois, J. L.; Poznanski, S.; Ribadeau Dumas, B. Fractionnement préparatif des caséines de vache et de brebis par chromatographie sur DEAE-cellulose en milieu urée et 2-mercaptoéthanol. Bull. Soc. Chim. Biol. 1968, 50, 521530.

Mitchell, J.; Irons, L.; Palmer, G. J. A study of the spread and adsorbed films of milk proteins. Biochim. Biophys. Acta 1970 , $200,138-150$.

Pearce, K. N.; Kinsella, J. E. Emulsifying properties of proteins: evaluation of a turbidimetric technique. J. Agric. Food Chem. 1978, 26, 716-723.
Sen, L. C.; Lee, H. S.; Feeney, R. E.; Whitaker, J. R. In vitro digestibility and functional properties of chemically modified casein. J. Agric. Food Chem. 1981, 29, 348-354.

Slattery, C. W. Casein micelle structure; an examination of models. J. Dairy Sci. 1976, 59, 1547-1556.

Swaisgood, H. E. Chemistry of milk protein. In Developments in Dairy Chemistry. 1. Proteins; Fox, P. F., Ed.; Applied Science: London, 1982; pp 1-59.

Turro, N. J. In Modern molecular photochemistry; Benjamin/ Cummings: Menlo Park, CA, 1978; pp 110-114.

Whitaker, J. R.; Puigserver, A. J. Fundamentals and Applications of Enzymatic Modifications of Proteins-an overview. In Modifications of Proteins: Food, Nutritional and Pharmacological Aspects; Feeney, R. E., Whitaker, J. R., Eds.; Advances in Chemistry Series 198; American Chemical Society: Washington, DC, 1982; pp 57-87.

Wilcox, P. E. Esterification. Methods Enzymol. 1972, 25, 596615.

Zittle, C. A.; Custer, J. H. Purification and some of the properties of $\alpha_{\mathrm{S}}$-casein and $\kappa$-casein. J. Dairy Sci. 1963, 46, 11831188.

Received for review September 29, 1989. Accepted February 20,1990 . 